\title{
History and the Internet: possible connections
}

\begin{abstract}
This paper investigates possible connections between History and the Internet. The starting point of this discussion is an acknowledgement of the presence of the Internet in social life, and its impact in the ways of obtaining and publicizing knowledge. More specifically, a discussion will be presented on how the Internet has been producing new documents for the work of historians and, better yet, how they have dealt with such sources. In order to do so, a few studies performed by historians are listed as utilizing the Internet as source. In this section, the idea is to point out what digital documents have been chosen by historians to perform their analyses, what difficulties they face, and what potential these sources have. It is understood that the Internet has great potential for historiographic work and, notably, for Present-Day History. The second part of this paper presents information on the research on Brazilian websites whose theme is historical landmarks, with the objective of investigating narratives produced and presented in school-level research websites about Brazilian historical landmarks. At this stage, the discussion is focused on debating the uses of History performed by these spaces. It is noticeable that they present narratives in which historical facts are presented linearly and in a simplified manner, following the so-called Traditional History. This two-way observation is expected to contribute with the debate on this important matter of the production and divulging of historical knowledge.
\end{abstract}

Keywords: History - Teaching and Learning, The Internet.

\section{Nucia Alexandra Silva de Oliveira}

Ph.D. in History from the Federal University of Santa Catarina (UFSC). Professor at the Department of History of the Santa Catarina State University (UDESC). Florianópolis - SC - BRAZIL nucia.oliveira@gmail.com orcid.org/0000-0002-3793-2480

\section{DOI: $10.5965 / 2175180311282019574$}

http://dx.doi.org/10.5965/2175180311282019574

\footnotetext{
* Translation of the article "História e internet: conexões possíveis" published in the Journal Tempo e Argumento, Florianópolis, v. 6, n. 12, p. 23-53, mai./ago. 2014.

${ }^{* *}$ Translated by Filipe dos Santos Avila and Fabiano Seixas Fernandes.
} 


\section{Resumo}

Este artigo pretende problematizar as conexões possíveis entre história e internet. $O$ ponto de partida de tal discussão é a constatação da presença da internet na vida social e dos impactos desta mídia nas formas de obter e publicar conhecimentos. Procura-se, de modo mais específico, discutir como a internet tem produzido novos documentos para o trabalho do historiador e, ainda, como tem lidado com eles. Para isso, listamse alguns trabalhos feitos por historiadores que utilizam a internet como fonte. Nesta parte do trabalho, a ideia é apontar os documentos digitais escolhidos pelos historiadores para a realização de suas análises, ad dificuldades encontradas e as potencialidades destas fontes. Compreende-se que a internet oferece grandes possibilidades ao trabalho historiográfico e, em particular, à História do Tempo Presente. Na segunda parte deste artigo são trazidas informações a partir da pesquisa intitulada "www.historia.com: uma investigação sobre marcos históricos brasileiros tematizados em sítios eletrônicos". Seu objetivo é investigar narrativas produzidas e apresentadas em sites de pesquisa escolar a respeito de marcos históricos brasileiros. Nesta etapa da discussão, o propósito é debater os usos da história feitos por estes espaços. Percebe-se que se têm apresentado narrativas em que os fatos históricos aparecem de forma linear, simplificada e seguindo o que se costuma chamar de história tradicional. Nesse duplo movimento de observação, espera-se contribuir com o debate sobre esta importante questão: produção e divulgação do saber histórico.

Palavras-chave: História - Estudo e Ensino. Internet. 


\begin{abstract}
"Diabo de menino agora quer Um i pod e um computador novinho Certo é que o sertão quer virar mar Certo é que o sertão quer navegar No micro do menino internetinho"
\end{abstract}

Banda larga cordel - Gilberto Gil

A hundred and five million internet users! This significant number, shown in a survey conducted by Ibope Media and published in several media outlets in 2013, highlights the upward and accelerated curve of this vehicle in Brazil 1 . Such data are highly expressive and illustrate why Brazil is known today as the fifth most connected country in the world.

This phenomenon certainly does not go unnoticed; the Internet is among the most commonly discussed themes in daily life, as may be evidenced by the increasing number of publications that tackle the subject from varying perspectives. There are, for instance, reflections on the reach of digital media in their impact on social relationships, on their educational possibilities, on their excesses and all sorts of problems they bring, among several topics, making us consider the Internet as a champion in terms of interest and notoriety.

It is important to remember that this medium was created in the United States, in the 1970s, springing from security-related projects. Since then, and especially from the 1990 s on, different types of technology have been created. In this sense, the Internet's reach grows and diversifies. It is worth mentioning the launching of the world wide web (www or web), an application conceived in the 1990 s to share data in a larger scale. Another innovation was web 2.0, a technology which, since 2004, has allowed for userbrowser interaction and is "responsible" for the emergence of social networks such as Orkut, Twitter, Facebook, among others (CASTELLS, 2004; BRIGGS and BURKE, 2004).

The proliferation of social networks and the prominent role they develop in the circulation of ideas are important historical and cultural phenomena in terms of media

\footnotetext{
${ }^{1}$ http://tobeguarany.com/internet-no-brasil/. Access on: 10 March 2014.
} 

to specify thus as a set of (material and intellectual) techniques, of practices and activities, of ways of thinking and values that develop alongside the growth of cyberspace (LÉVY, 1999, p. 17). Therefore, when discussing cyberculture, what is at stake is the emergence of activities and practices organized from a means of communication that have the so-called cyberspace as its locus of experience. Cyberspace, in its turn and according to the author, constitutes a new means of communication arising from the interconnection of computers (LÉVY, 1999, p. 17), and hosts information through which subjects navigate.

I do not see the Internet as more revolutionary than other media such as radio, cinema, or television. Each of them, in their own way, brought about some level of detachment, but also fascinated and gave way to learning experiences. Remembering what Gilberto Gil says in the lyrics cited in the epigraph, "the radio did to the Internet boy's grandpa the same it did for him: it let him discover the world!" Nor do I see the Internet replacing all these media. However, and as has been said throughout these considerations, it is worth highlighting the relevance of this instrument of communication, considering its implications and potential in such relevant questions as the construction and dissemination of historical knowledge.

The present paper thus joins the debate on the Internet's possibilities, dissemination potential and related phenomena on the study of History. I am interested in perceiving the possible connections between History and the Internet and their interaction. Therefore, on the one hand, I discuss how the Internet can be a locus for historiographical analysis, and, on the other, present some of the uses of History in school research websites. It is necessary to explain the interest for both aspects.

I understand that, with the emergence of the Internet, we conquered a significant growth in terms of research resources. By associating different works conducted by historians, it is expected that other reflections and sources produced on the Internet be disseminated and comprehended. 
In its turn, the second point of this discussion, concerning the uses of History by school research websites, justifies itself in this text from the research experience of perceiving the central role the Internet plays in education in our country. Thus, the project I coordinate is entitled www.historica.com: an investigation on Brazilian historical landmarks in websites ${ }^{2}$, developed at UDESC's History Teaching Laboratory (Laboratário de Ensino de História). When choosing my research object, I was interested in understanding how History of Brazil was thematized in the websites young students researched. Among other questions, this project aims at understanding what type of narrative on Brazilian historical landmarks is being constructed to this public, and how History itself is being understood.

There seems to have been little study on the potentials and problems of such a recent development as the Internet. Such an analysis does not propose any type of interdiction to the vehicle; to the contrary, it is important to realize that, regardless of negative or positive points, we have in our hands an undeniable technological revolution that can and should be understood in its multiple facets - including the historical one. Roger Chartier (2010) highlights this point considering that significant mutations in the construction, publishing, and reception of historical discourse have taken place when History entered the era of textuality. Chartier also states that electronic textuality transformed the modes of organizing and defining the criteria for accepting or rejecting arguments. This leads to the understanding that both reader and researcher of such texts are inserted in a new optics of reading, a challenging novelty, in the sense that old reading practices are put in question. After all, one is more often suspicious about what is found on the Internet, especially since many texts do not seem to have the same rigor as printed works, especially concerning references and explicit authorship.

Besides Internet's fluidity and any difficulty in analyzing its content and mode of organization, it should be said that it offers a singular tool to analyze latent questions in the field of Contemporary History. If the Internet represents innovation in media, it also

\footnotetext{
${ }^{2}$ The research was approved by the Programa Institucional de Iniciação Científica e de Desenvolvimento Tecnológico e Inovação PIC \& DTI (Institutional Program of Scientific Research and of Technology and Innovation Development) notice 2012/213 (UDESC), awarding an undergraduate research scholarship do History student Matheus Fernando Silveira.
} 

illustrate it.

\section{The Internet and its impact in the production of historical knowledge}

In a 2010 lecture in Porto Alegre, available on YouTube, Carlo Ginzburg (2010) discusses History in the Google Age $^{3}$. One of the central points in his argumentation is Internet's impact on the production of knowledge. Still according to him, tools such as Google do neither transform nor fragment our reading practices; to the contrary, they intensify the quantity of information we have access to. Google, therefore, has the function of provoking study; and still according to the Historian, such a tool is, without our questions, nothing more than a lifeless machine. Ginzburg, however, does not see the Internet as something democratic, but potentially democratic, considering that to use it one must have a specific grasp of certain knowledge, besides certain social domains that surround it.

I am interested in his claim that the Internet has provoked a change in the ways historical knowledge is produced. In face of the Internet and in the electronic present, the past dissolves itself and concepts such as present, past, and future become fragile, claims Ginzburg. I understand that such a statement is related precisely to the modes of acquiring information that, today, are not just accelerated, but often transitory. Thus, the question is the following: as historical data, this information, even if momentaneous and unstable, has major significance for the comprehension of today's ways of reading and writing our time, which cannot be forgotten by historians.

By analyzing the relationship between historians and the Internet, it must be said, at first, that they were attracted by the possibilities of communication and creation of discussion groups the Internet allows. It is also necessary to admit that there was a remarkable interest in the potential for forming and distributing databases. The idea of

\footnotetext{
3 https://www.youtube.com/watch?v=CqxPgtaRUvA
} 
great potential to create and disseminate databases among research peers. In the historiographic field, we must celebrate the possibility of building and spreading large archives, to the point that research restrictions related to geography will cease to exist.

Concerning the reflections on the potential of the Internet for the historian's work, it is important to highlight the relevance of Juan Andrés Bresciano's work, published in Uruguay in 2010, which proposes to discuss the methodological, discursive, and institutional innovations brought about precisely by the emergence of new technologies that introduce changes in the supports and formats of information, thus originating new classes of documents.

On the impact of digital multimedia culture, he states:

(i) Supone en sí mismo un fenómeno a estudiar, ya que se trata de un proceso de transformación mundial de particular relevancia.

(ii) Aporta un caudal inusitado de fuente para el conocimiento histórico, por el volumen y la diversidad de registro que produce.

(iii) Modifica el modo en que se obtiene la información y se genera saber. Dado que la Ciencia Histórica no es una excepción, también afecta a las prácticas de investigación sobre el pasado. (BRESCIANO, 2010, p. 12. $)^{4}$

The main objective of the Uruguayan Historian is to observe how such changes are accompanied by Historiography in instances of creation and communication of knowledge about the past. I consider him to be relevant precisely for presenting a systematic discussion on issues such as broadening the concept of historical source by the incorporation of new forms of record, the impact of new digital resources in fieldwork, and the appearance of a critique on such electronic resources and documents. On the other hand, it is also worth praising the presentation of the so-called discursive and

${ }^{4}(\mathrm{i})$ It is supposed a phenomenon to be studied, since it is a process of world transformation and of relevance. (ii) It provides an unusual flow of sources for historical knowledge by the volume and diversity of records it produces. (iii) It modifies ways of obtaining information and generating knowledge. Since historical science is not an exception, it also affects investigation practices about the past. (All footnote translations are ours.) 
and documents), Bresciano perceives a change in the way of producing Historiography. He reminds us that History, since its consolidation as a science, is linked to a set of practices, readings, and procedures of writing and investigation. That is, functions, tasks, and uses regulated through time, and that now start to have new dimensions resulting from the new technologies. He summarizes:

De este modo, surgen espacios destinados exclusivamente al cultivo de una Historiografía que puede clarificarse de digital, por las fuentes a las que acude, por las herramientas analíticas que utiliza y por el discurso que emplea5. (BRESCIANO, 2010, p. 89.)

Discussing the emergence of Digital Historiography, historian Anita Lucchesi (2012; 2013) offers important data to the comprehension of how historians are beginning to use the Internet. She shows how two groups, or rather two historiographic tendencies that have contributed to building the field of Digital Historiography, interact and clash: the Italian branch, called Storiografia Digital, and the American one, Digital History. In her words: "Trata-se de dois polos de estudos que, a nosso ver, encerram duas tendências historiográficas afins, porém, distintas entre si” (LUCCHESI, 2013, p. 2) ${ }^{6}$. In Lucchesi's understanding, studying these two tendencies and, therefore, tracing the development of a digital historiography is one of the means to understand the ways through which historians deal with the new problems brought about by this contact between History and the Internet.

In the United States, the emergence of so-called Digital History can be traced to the 1990s, when projects in the area of new media were developed at the George Mason University Center for History and New Media (CHNM). This space presented proposals to preserve the past by means of initiatives that employed digital technologies that sought

\footnotetext{
${ }^{5}$ Thus, spaces destined exclusively to cultivating a Historiography that can be classified as digital, due to the tools, sources, and discourse they employ, start to appear.

${ }^{6}$ They are two poles of study that, in our view, comprise two similar but distinct historiographic tendencies. Our translation.
} 
gathering, preserving and presenting the past on the web. We can consult the website to learn about its proposal: History Digital is a guide that lists the possibilities to produce an "online historical work". In this sense, the e-book tackles, step by step, issues, from drafting a project to reaching a readership. It also discusses themes such as copyrights, interactivity techniques, digitalizing material, and, finally, "basic orientations on how to guarantee that the digital history created by the reader won't disappear in a few years"7.

The Italian Storiografia Digitale, in its turn, was conceived from Rolando Minutti's propositions (Modern History scholar at the Department of Geographical and Historical Studies at the Università degli Studi di Firenze, Florence, Italy). In 2001, he published Internet e il mestiere di storico - Reflessioni sulle incertezze di una mutazione [Internet and the historian-Reflection on the uncertainty of a transformation], in which he offers his reflections on the doubts and possibilities lived by historians who lived the "digital revolution". Such reflections were received empathically; an example of this phenomenon is the release, in 2004, of other works on the same theme such as La Storiografia Digitale (organized by Dario Ragazzini), in which historians and researchers from other areas continue the debate the use of the Internet in their research. In Lucchesi's understanding (2013), these works do not present definitive results, given the reflexive character of the theme, but they highlight significant aspects about what these authors expect of the so-called digital revolution. Commenting Minutti's work, Camila Dantas (2008) highlights that the central theme of his proposal and the motto for this publication are related to the positive impacts new information technologies have on contemporary Historiography, as well as new perspectives for historians. According to her, launching this project did not intend to change the "historiographical operation" term coined by Michel de Certeau - to the contrary, the idea was to bet on diversifying writing procedures:

${ }^{7}$ Available at: http://chnm.gmu.edu/digitalhistory/ Access on: 10 April 2014. 
Autores como Minutti não propõem tal mudança e advertem que o fato de se poder utilizar o hipertexto não significa uma adesão a uma perspectiva relativista de que qualquer percurso informacional seja válido. Ao contrário, procura-se mostrar a necessidade de se refletir sobre as tecnologias e experimentá-las criativamente (DANTAS, 2008, p. $59)^{8}$

These two historiographical paths, Digital History and Storiografia Digitale, illustrate the same process of interest and search of new paths to write History, taking the Internet as a tool and research source. As Lucchesi (2013, p. 5) ponders, we witness the "surgimento de um novo campo de estudo, de uma nova área do saber no interior da história: a pesquisa e a formação em 'historiografia digital', donde decorre nossa tomada da relação entre História e Internet como um "novo problema” para a nossa disciplina"9. Therefore, what is digital historiography? Lucchesi informs that French historian Serge Noiret, member of the Italian group, is the one who presents the concept, stating that such studies concern scientific works that use the Internet to be propagated and are based on the hypertext for a reelaboration of historiographical writing, frequently incorporating the sources themselves and part of the consulted elements in the conduction of the research (NOIRET apud LUCCHESI, 2013, p. 6).

As is possible to perceive from this conceptualization, to speak of digital historiography is to focus on the possibility of spreading scientific works and incorporating different types of Internet materials to the works of historians. In Brazil, concerning studies on the Internet and, more specifically, on the relationships between the Internet and history, it is possible to say that the interest has also grown recently, but it should be noted that the field is still on its way to be consolidated. Research on the World Wide Web and on graduate programs and university library databases shows this dimension, for the number of works related to History and the Internet is scarce. Next, I present some examples I found, selected to illustrate the sources utilized in such works, as well as to evidence the theoretical and methodological sources of the authors.

\footnotetext{
${ }^{8}$ Authors such as Minutti do not propose such a change and warn that being able to use the hypertext does not mean adhering to a relativist perspective that any informational path is valid. To the contrary, they seek to show the need to reflect on technologies and experiment them creatively.

9 [A] new field of study emerges, a new area of knowledge inside History: research and education in "digital historiography”, whence our decision making between History and the Internet as a 'new problem' for our discipline springs
} 
We must admit that several works whose themes and sources are raised by means of the Internet are concentrated in programs and laboratories dedicated to History of the Present. For instance, at the History Graduate Program at the State University of Santa Catarina (UDESC), the master's thesis From on-line to off-line: sociability and written culture provided by the Internet in 21st century Brazil (2001-2010) was presented by Pedro Eurico Rodrigues in 2012. It analyzes practices of sociability, construction of the self, and musealization of the self by means of the study of an Orkut community and a blog. More specifically, the research sources of this work are narratives produced by female users of the social network; the researcher sought to perceive new ways in which they establish friendships, project self-images and safeguard them digitally. To tackle this theme, the historian draws upon History of Written Culture and Reading, establishing a dialog with Robert Chartier's work. In its turn, the methodological choice highlights the conceptualization and interpretation of the materials under analysis as examples of a "new protocol of reading and writing", as well as new sociabilities. From this understanding, sources - narratives produced by subjects who participate in the communities - are analyzed as examples of the modest of construction of the self and of social experience in the present time.

In the same program, Julia Massuchetti Tomasi defended the thesis "Eternally offline": mourning practices in the social network Orkut in Brazil (2004-2011). This work analyzes Orkut as an environment for the expression and sharing of pain and mourning in messages and images in the pages of this virtual community. Through these narratives and images, the researcher seeks to understand the new forms of sociability, as well as the relationships of interaction experienced among these users. The work also aims at discussing the research through online documents, created in the communities of the social network. The researcher highlights that this work was built in close contact with questions posed by History of the Present concerning, particularly, the selection of fonts for the thesis and the analyses that can result from them.

Both theses show one of the possibilities of historiographical work from sources created on the Internet. Orkut, Twitter, Facebook, and other narrative-production mechanisms, such as blogs, have been identified by historians as perception spaces with 
Therefore, this serves as evidence that, through narratives produced on the Internet, it is possible for historians to have access to new ways of producing memory and perceiving events in their own time.

Another focus of study is spaces created on the Internet as places for conserving memory. This is, for instance, the theme of Camila Dantas' Master's thesis from the graduate program in Social Memory at the Federal University of Rio de Janeiro in 2008. The researcher, with a degree in History, presents a study from a digital archive called People's War (created in 2003), compiling 47 thousand online testimonials and 15 thousand images related to British social memory on World War II. Using bibliography on social memory, History, and construction of digital patrimony, the researcher seeks to discuss the material presented in the archive as a study source for a perception of how relationships between History and memory on the Internet are established. In this study, Dantas understands that there is a synchrony between official memory and memory as presented in the project, despite some dissonant voices. Another perception is the fragmentation of the testimonials, which she relates to the specificities of this type of technology and the forms of reading on the computer (DANTAS, 2008, p. 5).

The spaces created on the Internet that allow a reflection on the so-called public uses of History are also another field of analysis. Professors Sebastián Plá and Xavier Rodríguez Ledesma, from the Pedagogical University of Mexico, conducted an instigating work on this theme. They conduct research questioning the approximations and limits between school History, Twitter History, and a public and political dispute for the resignification of certain Mexican historical characters. The researchers start from an important observation: currently in Mexico schools do not hold the monopoly of the past, and varied means of mass communication have been using it. In this fight for representation and legitimacy, therefore, school, television, cinema, and Internet itself "duel" as bearers of narratives worth of being attested as "true". As for Plá and Ledesma's research, characters called historical tuiteros appear in the social network as 
conclusion that the tuiteros seek to occupy an intermediate place between Historical and public knowledge and develop considerable empathy among the followers and the characters they seek to personify through the historical figures they seek to resignify. It is worth highlighting that they work considering the realization of a virtual ethnography. As they define it themselves, "es un trabajo de corte cualitativo, con carácter exploratorio basado en principios de la etnografía virtual, es decir, es una primera aproximación que nos permitirá describir las características del uso de identidades históricas em Twitter”10 (PLÁ, LEDESMA, 2013, p. 142). From the understanding that the cyberspace represents a great potentiality for the study of means and communications, as well as questioning certain dualities such as real/virtual, truth/fiction, representation/reality, among others, authors opt for a reflection that considers the Internet as a cultural artifact.

The examples here listed seek, within the limits of an article, to exemplify the possible themes from the understanding of the Internet as a source for historical work. I shall come back to them, as some explanations are necessary to emphasize especially the potential and difficulties faced by the researchers. Before moving on, I would like to change my focus, and address the propagation of historical contents on the Internet.

\section{Brazilian History in school research websites ${ }^{11}$}

How does the Internet present History of Brazil contents? That is the exact questions that led to the construction of a research whose main objective was to identify and problematize historical narratives related to Brazilian historical landmarks available in school research websites. Such an idea sprang initially by observing the need to

\footnotetext{
10"It is a work of qualitative scope, with exploratory character based on virtual ethnography principles, that is, it is one of the first approximations that will allow us describe the characteristics of the use of historical identities on Twitter".

11 Some of the issues presented under this heading were tackled in "Internet, History Teaching, and the Historical Culture of Brazilian Youths", presented at the 10th National Conference of Education Researchers at the Federal University of Sergipe, from 15 to 17 October 2013.
} 
historicize and understand the Internet as space for records, information, and production of knowledge. From another perspective, this is due to the central position this vehicle holds in the school environment, considering that Brazilian students of all levels use the Internet in their assignments ${ }^{12}$.

I believe that the use of different types of materials (texts, images, documentaries, etc.), available on the Internet as knowledge building resources, must be understood to raise awareness to the type of knowledge being circulated, and how it integrates students' knowledge. Thus, as a research object, the project I coordinate analyzes school research websites, seeking, specifically, to investigate History of Brazil contents published in these spaces. Thus, I recall the proposition presented by Klaus Bergmann in his text on History Education. In this text, Bergmann ponders that reflecting on History from concerns with History Education means to "investigar o que é aprendido no ensino de História (tarefa empírica da Didática da História), o que pode ser apreendido (tarefa reflexiva da Didática da História) e o que deveria ser aprendido (tarefa normativa da Didática da História)"13 (BERGMANN, 1990, 29). I believe the task of analyzing school research websites is linked to the reflexive task of History Education, that is, to what can be learned. I believe, therefore, the contents presented in such websites make up the learning about history of those conducting school research that go to them and use their texts and images.

Before developing this reflection, I find it necessary to start the discussion with a presentation of the methodological organization of the present work.

The first step of the present research was "searching for the websites". Thus, I looked for websites containing the key expression "History of Brazil". We then systematized ${ }^{14} 15$ electronic addresses for a more detailed inquiry and further data collection. Thus, we conducted a general reading of each website, which led us to finding

\footnotetext{
${ }^{12}$ During Supervised Internship and in the Teaching Internship Program (PIBID), investigation questionnaires are applied to basic education students. One of the questions is precisely about the use of the Internet. It has been perceived that students utilize school research websites systematically in their assignments, and that they are connected most of the day.

${ }^{13}$ investigate what is learned in History (empirical task of History Education), what can be learned (reflexive task of History Education), and what should be learned (normative task of History Education).

${ }^{14}$ I refer here to the work conducted by Matheus Fernando Silveira and I. Silveira is an undergraduate researcher who participated in all steps of the research from August 2012 until August 2014.
} 
the necessary selection criteria for a more detailed analysis, considering the considerable volume of each website. We thus opted to work with eight websites for data collection. These are:

www.historiadobrasil.com.br;

www.historiadobrasil.net;

www.historiadobrasil.net;

www.brasilescola.com/historiab;

www.suapesquisa.com/historiadobrasil/;

www.educacao.uol.com.br/historia-brasil;

www.bussolaescolar.com.br/historia.htm;

http://www.alunosonline.com.br/historia-do-brasil:

http://www.mundoeducacao.com.br/historiadobrasil.

After this survey phase, the websites were accessed in order to characterize where the information to be analyzed was stored. The idea, then, was to read through each website with attention, seeking to map the existence, or not, of authorship in the texts, the definition of a target audience, and a goal or set of policies. In this sense, we found that some of them bring information about the way in which they are organized, or about how they seek to inform how their content is constructed, about their authors and target audience, as well was a concern in sharing their privacy policies. Concerning such data, I noticed that some are more complete than others, but it is possible to say that a common characteristic among them is a search to legitimatize their content. I understand this preoccupation as a relevant element to the websites' need to attest their veracity. This issue is related to a common discussion concerning material found on the Internet: a suspicion about the authenticity of the information, data manipulation, and problems of plagiarism and lack of authorship.

Roger Chartier (2010) signals that, in the world of textuality, the elements that attest the veracity of a text are much more diluted than in print. Concerning a History text, the notes, bibliographical references, and citations seek to establish a confidence pact between author and reader. In the world of textuality, the reader/user can consult documents they previously could only have access to through the author's reading. This 

their content.

The website "www.suapesquisa.com" presents information on how to contact them, its objectives, user profile, bibliography, privacy policies, among others. It is worth highlighting, among these, the presentation of the arguments that explain the objective of creating the website: "share scientific, historical, artistic, and cultural knowledge". Concerning the originality of the texts, it states:

Os textos são elaborados por nossa equipe, que é formada por especialistas em diversas áreas do conhecimento. Todos os nossos textos são originais e não simples cópias de enciclopédias ou de outros sites. Optamos por utilizar um design simples e agradável e uma linguagem didática para que todos possam entender corretamente as informações. ${ }^{15}$

Following the course of our methodology, data collection takes place after websites are classified. Data collection was thus structured: a historical fact is chosen for analysis; each website is then accessed for information collection. Initially, the theme is located within the website, as well as the presence of related links. Then, a database is put together, containing images and texts organized in tables. Besides selecting the text, a reading is also conducted to record impressions. The following questions are considered: what type of information is provided? Is it complete or summarized? Is it critical or not? Does it potentialize the study or does it merely inform the reader? Does it propose reflections beyond the text? Does it reference other research? Is the author mentioned?

This is similar to analyzing printed material, but with a significant difference: the various links available in the websites, considering that, different from printed material, intertexts have a specific structure that allows them to open multiple "windows" according to the author's and the reader/user's wishes.

\footnotetext{
15 Cf. www.suapesquisa.com. Access on 10 April 2013: Our texts are elaborated by our team, which is comprised of specialists in various areas of knowledge. All our texts are original and not merely copies of encyclopedia or other websites. We choose to have a nice and pleasant design and a didactic language so that all can correctly understand the information.
} 
Thus, I present some considerations from the data researched.

The Discovery of Brazil was the first historical landmarked to be researched. Choosing this theme was due to its frequent position, in a Eurocentric perspective, as a starting point for our history. One of the first findings was that, majoritarily, websites bring texts in a compartmentalized way. That is, from the search of "Discovery of Brazil" we find several separate themes, such as: Pedro Álvares Cabral, Pero Vaz de Caminha's Letter, Treaty of Tordesillas, etc. Moreover, I perceived that the texts are short and objective, since the narratives usually only contain general/punctual information: when a fact occurred, who was involved, and some explanation on why it happened. Observing "suapesquisa.com", we note that the browser finds a series of topics in its entry page; among them, there is the option to research the History of Brazil. By accessing such items we arrive at a list of different contents, among them the Discovery of Brazil, and, finally, by clicking on the list, we have, again, segments with new links to the following items: historical context; the arrival of the Portuguese in Brazil; first contact with the natives; controversy: discovery or arrival?; main historical source; and curiosities. Each heading has a brief description of what will be presented. Thus, in the item that covers the arrival of the Portuguese to the "new land", we have the following:

O Descobrimento do Brasil ocorreu no dia 22 de abril de 1500. Nesta data as caravelas da esquadra portuguesa, comandada por Pedro Álvares Cabral, chegou ao litoral sul do atual estado da Bahia. Era um local [em] que havia um monte, que foi batizado de Monte Pascoal. No dia 24 de abril, dois dias após a chegada, ocorreu o primeiro contato entre os indígenas brasileiros que habitavam a região e os portugueses. De acordo com os relatos da Carta de Pero Vaz de Caminha, foi um encontro pacífico e de estranhamento, em função da grande diferença cultural entre estes dois povos. ${ }^{16}$

This text brings into discussion a somewhat simplified version of the event. In it, facts are told in a sequential exposition of what possibly happened. That is, the discovery

\footnotetext{
${ }^{16} \mathrm{Cf}$.www.suapesquisa.com. Access on 12 October 2012: The Discovery of Brazil took place on 22 April 1500. On this date, the caravels of the Portuguese squad, commanded by Pedro Álvares Cabral, arrived in the southern shore of what is today the state of Bahia. There was a mountain there, which was named Monte Pascoal. On 24 April, two days after the arrival, the first contact between the Native Brazilians and the Portuguese. According to Pero Vaz de Caminha's letters, it was a peaceful yet estranging encounter due to the big cultural difference between these two peoples.
} 
is narrated, but not problematized as a historical fact should be. It is still worth highlighting the reference to Caminha's Letter, remarkably used to punctuate the peaceful character of this encounter where a "natural" estrangement took place, considering the differences of the two peoples. It should be highlighted that this type of narrative naturalizes the fact, since it does not offer any discussion about it, neither does it suggest such a discussion to the user/researcher. That is, this text does not present the student the challenge of doubt or a historical reflection. The narrative about the historical fact - the discovery of Brazil - appears ready and finished.

Analyzing other websites, similar perspectives are found, such as in "historiadobrasil.net", a website that, as the same suggest, is dedicated to themes of our History. The website presents period of our History in three major sections: Colonial Brazil, The Brazilian Empire, and the Brazilian Republic. Beyond this division, it brings the possibility of navigating through a tab with documents of Brazilian History and films and documentaries about such themes. The Discovery of Brazil is in the section Colonial Brazil. On this subject, we found an illustrated text reproducing an Oscar Pereira painting. Strangely, there are no subtitles to identify the painting, which is simply accompanied by the phrase "first contact between the Portuguese and the natives". The fact, as previously said, is presented in a single text that begins thus:

Em 22 de abril de 1500 chegava[m] ao Brasil 13 caravelas portuguesas lideradas por Pedro Álvares Cabral. À primeira vista, eles acreditavam tratar-se de um grande monte, e chamaram-no de Monte Pascoal. No dia 26 de abril, foi celebrada a primeira missa no Brasil. ${ }^{17}$

Again, as we can read, it is a synthesized narrative of a sequence of events, or another text that describes the Discovery and informs its most basic circumstances.

The Independence of Brazil was also a research theme. Its analysis was incremented with studies on narratives referring to D. Pedro I. In the website "suapesquisa.com", the theme appears on the (aforementioned) list of contents. By

\footnotetext{
${ }^{17} \mathrm{Cf}$. www.historiadobrasil.net. Access on 20 October 2012: On 22 April 1500 thirteen caravels, led by Pedro Álvares Cabral, arrived in Brazil. At first sight, they believed it to be a big mountain and called it Monte Pascoal. On 26 April the first mass was celebrated in Brazil.
} 
economic, and social transformations; dependence of England in Brazil. The text that introduces the theme is the following:

A Independência do Brasil é um dos fatos históricos mais importantes de nosso país, pois marca o fim do domínio português e a conquista da autonomia política. Muitas tentativas anteriores ocorreram e muitas pessoas morreram na luta por este ideal. Podemos citar o caso mais conhecido: Tiradentes. Foi executado pela coroa portuguesa por defender a liberdade de nosso país, durante o processo da Inconfidência Mineira. ${ }^{18}$

In this introduction, it is possible to perceive that the independence is presented as an instant rupture from Portuguese rule and the beginning of the country's autonomy. Another aspect to be detected is the reference to Tiradentes's death for the "ideal" of independence, which is narrated separately from the context of the Minas Gerais Conspiracy. Besides, it does not reference Portuguese continuity in Brazil, implicit by the fact that D. Pedro became emperor. These aspects could be considered minor, or content details. However, they need to be pointed out and discussed, for, I insist, it is evident that the websites' narratives simplify historical events.

Another point of concern is the personification of decisions or events. In this case, this happens when the narrative is presented focusing on D. Pedro l's posture and decisions, described as the main causes of this movement.

Em 9 de janeiro de 1822, D. Pedro I recebeu uma carta das cortes de Lisboa, exigindo seu retorno para Portugal. Há tempos os portugueses insistiam nesta ideia, pois pretendiam recolonizar o Brasil e a presença de D. Pedro impedia este ideal. Porém, D. Pedro respondeu negativamente aos chamados de Portugal e proclamou: "Se é para o bem de todos e felicidade geral da nação, diga ao povo que fico.". [...]

\footnotetext{
${ }^{18} \mathrm{Cf}$. www.suapesquisa.com/independencia. Access on 14 April 2013: The Independence of Brazil is one the most important historical facts of our country, as it marks the end of Portuguese rule and the conquest of political autonomy. Many previous attempts took place and many people fought and died for this ideal. One of the most familiar facts involves Tiradentes. He was executed by the Portuguese crown for defending freedom in our country during the Minas Gerais conspiracy.
} 
Após o Dia do Fico, D. Pedro tomou uma série de medidas que desagradaram a metrópole, pois preparavam caminho para a independência do Brasil. D. Pedro convocou uma Assembleia Constituinte, organizou a Marinha de Guerra, obrigou as tropas de Portugal a voltarem para o reino. Determinou também que nenhuma lei de Portugal seria colocada em vigor sem o "cumpra-se ", ou seja, sem a sua aprovação. Além disso, o futuro imperador do Brasil, conclamava o povo a lutar pela independência. ${ }^{19}$

Such a narrative, that presents D. Pedro I's political and administrative actions as mainly responsible for our independence process is strengthened when the website presents a biography of this Brazilian icon. See the following text:

Desde criança apresentou forte espírito de liderança. Quando, aos 22 anos, assumiu o governo brasileiro na condição de príncipe regente, agiu como brasileiro visando aos interesses de nosso povo. Também por este motivo, decidiu ficar no Brasil quando a corte portuguesa o chamou de volta a Portugal. Nessa ocasião, conhecida como Dia do Fico (9 de janeiro de 1822), ele demonstrou seu grande amor pelo Brasil, levando-o a proclamar a nossa independência em 7 de Setembro de $1822 .{ }^{20}$

This type of narrative, which glorifies heroes, is problematized among researchers of History Education and History of Brazil. Thais Fonseca (2011), upon studying the development of this subject in Brazil, pointed out different uses of narratives on great figures/heroes and the glorification of facts. According to her study, the institution of the subject in Brazil accompanies a bigger context of creation and consolidation of the idea of a national state, which meant, precisely, the use of heroes and events taken as remarkable in the history of Brazil.

\footnotetext{
${ }^{19} \mathrm{Cf}$. www.suapesquisa.com/independencia. Access on 14 April 2013: On 9 January 1822, D. Pedro I received a letter from the Portuguese court demanding his return to Portugal. Long have the Portuguese insisted on this idea, for they intended to recolonize Brazil and D. Pedro's presence prevented this ideal. However, D. Pedro answered negatively to the calls from Portugal and proclaimed: "Since it is for the good of all and general happiness of the Nation, tell the people that I'm staying.". [...] After the Dia do Fico, D. Pedro adopted a series of measures that displeased the metropolis, since they paved the way for the Brazilian independence. D. Pedro convened a constituent assembly, organized a War Marine, forced Portuguese troops to go back to the kingdom. He also determined that no Portuguese law would be put in practice without his approval. Besides, the future emperor of Brazil claimed the people to fight for independence.

${ }^{20} \mathrm{Cf}$. www.suapesquisa.com/independencia. Access on 14 April 2013: From an early age, he showed a strong leadership spirit. At the age of 22, when he came into power as prince regent, he acted as a Brazilian addressing our people's interest. For this same reason, he decided to stay in Brazil when the Portuguese court called him back to Portugal. On this occasion, known as the Dia do Fico (9 January 1822), he showed his great love for Brazil, leading him to proclaim our independence on 7 September 1822 .
} 
It is also important to cite the websites that seek, in some way, to expose facts that diverge from this more "traditional" type of narrative. This is what we find in the website "educacao.uol", which talks about the independence without centralizing the discussion around the figure of $\mathrm{D}$. Pedro and without isolating the fact in a one-day event:

Em 7 de setembro de 1822, o Brasil livrou-se da condição de colônia, conquistando sua independência política. $O$ movimento de independência foi o resultado de uma forte reação das camadas sociais mais abastadas, às pretensões e tentativas das Cortes de Lisboa de restabelecer o pacto colonial.

Mas, para entendermos os acontecimentos que culminaram com o movimento de independência, é necessário considerar o período de permanência do governo português no Brasil. A partir daí ocorreram importantes transformações políticas, sociais e econômicas que marcariam os últimos anos do domínio colonial lusitano. ${ }^{21}$

It is important to find this type of narrative, since it shows that not all texts published on school research websites present personalized or simplified narratives. Therefore, there isn't a single discursive model on the websites.

The idea of presenting such examples from a research conducted on school research websites intends to give visibility to a type of use and publication of historical contents on websites dedicated, in this case, to school research. The discussion justifies itself in many aspects; one of them, already mentioned, is that students of all levels often use such websites. I understand that History teachers should use the Internet as an educational resource and that it must dialogue with the material presented and produced on the internet. After all, such contents have helped shaping the historical culture of students-users. As previously mentioned, conducting such a task is to pay attention to the reflexive task of History Education, according to Bergmann. In this sense, it is also valuable to reference Jörn Rüsen (2012), when he writes on historical culture and historical learning. According to him, when one understands History Education as the science of historical learning, it is about historical culture as a learning process (2012, p.

\footnotetext{
${ }^{21}$ http://educacao.uol.com.br/disciplinas/historia-brasil/independencia-do-brasil-brasil-livra-se-da-condicaode-colonia.htm. Access on 21 April 2013: On September 7, 1822, Brazil was rid of its colonial condition, conquering its political independence. The independence movement resulted from a strong reaction of the wealthier classes to the intentions and attempts of the Portuguese court to reestablish the colonial pact. But, to understand these events that led to the independence movement, it is the necessary to understand the period the Portuguese government stayed in Brazil. Thus important political, social, and economic transformations took place, which would mark the last days of Portuguese colonial rule.
} 

proposes, it is important to know such aspects to understand how historical learning takes place and how it is developed. Thus, I understand that thinking and seeking information on what students read, as well as on how they conduct their school assignments using school research websites, are ways of reflecting on their historical culture.

In this sense, it is convenient to ask: In what ways do school research websites in Brazil contribute to the development of historical culture and, consequently, to students' historical learning?

I understand (and, in this sense, I need to remember that analyses on this theme as in the vast majority of issues - are provisional and contextualized) that school research websites present contents that do not differ much from encyclopedias and general history/Brazilian history content-focused textbooks. Moreover, many such websites could be considered electronic encyclopedias, since they contain considerable volumes of texts in which historical facts are presented in a simple manner, no more than simple information, adding a few names and important dates. This leads us to the question: do the authors of such websites consider this to be the historical learning students should have? Should History be taught as a synthesized compilation of facts? We should, however, remember that many websites that go beyond a merely informative model. Anyhow, it is worth reflecting that, in both cases - however traditional narratives may be -, this type of writing represents an important role in the development of a historical culture in young Brazilian students and in their own understanding of History.

From the examples here cited, the following issues may be listed: historical knowledge is presented by means of synthesized narratives; the narratives lack problematization; on the contrary, they are presented as truths; personification is employed to portray major historical figures, and these are shown as responsible for historical facts. It is thus important to reflect on which perspective on History and History teaching is present in these websites. The previous exposition shows they subscribe to 
thought parameters from foundational perspectives of the discipline in the 19th century. These websites are concerned with the need for methodological rigor in favor of scientific historic truth, with an objective reading of sources, with the neutrality of the author in research and writing, among other issues that are currently thought differently. In today's historiographical practice, questions such as document criticism and interpretation, and the very affirmation of the researcher's subjectivity are understood as positive and important points. This points, therefore, to a contradiction in the object under analysis, which is the content of school research websites. These could offer historical narratives permeated by the possibilities of interaction with the content. It would also be possible to "open the links" directly with historians and their work, or still with archives where historical documents could be consulted. Finally, the websites could offer users a less "prêt-à-porter" version of History. As school research websites, I understand that their role should be providing access to contents that help to develop historical learning. I claim, however, that they are not in keeping with current discussions about History teaching.

After all, what does it mean to learn History? Rüsen's reflection on historical learning highlights that it can be understood as a mental process of constructing meaning about the experience of time through the historical narrative (RÜSEN, 2010, p. 43). Learning History is thus much more than memorizing names, dates, or ready-made versions of events formulated by someone else. The learning of History may to be used in everyday life (another idea presented by Rüsen), which supposes that students develop their own conclusions and expose them in narratives. For this, they need to be in contact with historical evidence so that they can utilize, compare, and, finally, cognitively develop their historical thinking. When I perceive that such websites present few tools for students to experience this construction of meaning, I understand that they (still) have little to offer concerning the teaching of History.

\section{Final Remarks}

The emergence of the Internet changed the way of dealing with the amount and availability of information. However, I feel inclined to believe that this does not mean a 

productions. It is a novelty that places the reader/user before the possibility of a more immediate interaction with what is being read, since this technology allows the immediate production of commentaries or even the creation of specific and individual spaces to share ideas.

The proposal of the present paper, as stated in our initial remarks, stemmed precisely from the wish to debate the presence of the Internet as a space to spread information and experiences of social relationships intensified by the acceleration in the forms of communication provided by this media phenomenon. Its specific interest is linked to the understanding and possible uses of such phenomena within historiographical work. For this, I sought to exemplify the uses that historians made of digital sources produced, for instance, in social networks such as Orkut, Facebook, and Twitter. I was able to perceive that there is great potential in such sources, and that they raise instigating investigations, especially in the fields of History Education and History of the Present. I understand, now, that it is important to make a few closing remarks, consequently, open for new debates on the theme.

The first consideration I would like to draw is that the Internet has been consolidating itself as a space of historical analysis. However, it still lacks a theoretically and methodologically grounded discussion. Examples of works created from digitallycreated documents have shown the following possibilities for reflection: the public use of History in social networks; the creation of sociability spaces and construction of self in narratives published in personal profiles; and even spaces for the creation and publishing of memories of the past.

Following the choices made by the researchers cited as examples, it is possible to perceive that they bet on material documents created within a new logic of communication and circulation of ideas and elected them as such. In this sense, I sought to list a few of their methodological choices, and I must say that there is, in their statements, nearly a consensus that, to write such works, it was necessary to seek, in the 
already established historiographical references, a first way of approaching the documents under analysis. That is, even with a different support from written culture, they opted to deal with the assumptions they use when dealing with written texts. I understand this option, precisely due to the initial stage of this History-Internet relationship. Thus, I found references to Chartier's studies on written culture when, for instance, Pedro Eurico presented his analysis on the textual construction of bloggers, which he analyzes in his thesis. On the other hand, it must be said that the dialogue between other areas of knowledge reflecting on the same question has been intensified. It is in this focus that we find, among the works previously analyzed, the incorporation of propositions made by philosopher Pierre Lévy to understand the phenomena of cyberculture and cyberspace.

As author of research that uses digitally constructed documents available on the Internet, I have also been opting to conduct "adaptations" in the methodological paths to conduct my work. In this sense, the project I coordinate followed similar procedures to the other works I analyzed in the present article. Parameters for content selection and reading were thus made drawing upon Chartier's reflections on History of Writing. Certainly, despite the difference in support, these are still textual narratives. However, in order to avoid that the specificity of structure be forgotten when reading texts taken from websites, the following problem must be considered: on the Internet, content can disappear or be quickly replaced, which leads to the problem of constant change in terms of the content under analysis. In the case of the research I coordinate, it did happen once that one website had its content modified, thus creating the need of a new reading. This could become a very serious problem, because you cannot always research everything anew. In this case, it must be said that, when organizing the documents, it is not advisable that the only access to them is online. Storing the material collected is an essential step when working in the virtual space.

Another important consideration concerns the narratives presented on the web on History and the meaning of such constructions. It is worth remembering what François Hartog (2006) writes in his discussion on the ways with which we deal with the past, also inserting here the concerns provoked by Beatriz Sarlo (2007). Hartog, when writing on 
historicity regimes, punctuates that we live under the regime of historicity (presentism) that seeks and centralizes itself in the present, and it is this experience that promotes our relationship between time and History. He offers a timely evaluation of the 2oth century, highlighting that, in its final third, it remarkably "gave a bigger extension to the category of the present: a massive, invading, ubiquitous present, that does not have a horizon beyond itself, daily manufacturing the past and the future it needs" (HARTOG, 2006, p. 270). On the other hand, Sarlo writes that the "views on the past are constructions" ( $p$. 12), and that narrating the past presupposes operations of liberation of enslavement orchestrated by situations of the present. And, if narrating is choosing, what to say about the choices presented by the websites analyzed here? I refer once more to Sarlo to argue that such narratives are in contact with academic History (after all, they commune in its ideals and cite it in some of their references), but seek to present a more synthesized version, considering they will be presented outside of a school environment. For Sarlo, in the historical narratives of wide circulation, a closed hermeneutical cycle unites the reconstitution of the facts to the interpretation of their senses, and guarantees global views, those that, in the ambition of 19th century's great historians, were the syntheses that today are considered either impossible or undesirable, and, in general, conceptually wrong (SARLO, 2007, p. 12-13).

Internet texts present a combination of official History, but also a more specific way of narrating the past, not necessarily organized with historiographical rigor, which puts us before the dilemma of how to deal with such narratives. By excluding them? No! I believe that more than denying these narratives, we need to contextualize them and understand them through the lenses presented by Hartog and Sarlo, of the use of past as spectacle only celebrated when in the interest of the collectivity. I remind you that historical landmarks presented on the websites analyzed here reinforce important moments of our History and are, in this sense, memories of a past they intend to glorify. Thus, it is worth noting that they seem to interact more with a desire for memory than with the problematization of History. Once more, Sarlo's words are provocative: “The non-academic modality (even if practiced by academically trained historians) listens to the common meanings of the present, answers the beliefs of its audience, and is oriented 
sought to be problematized, since it harms users' understanding by offering them such a fragmented and unchallenging perspective of the development of historical learning as defended by Rüsen.

Finally: what are the possible connections between History and the Internet? I'd say they're countless! This is also true of the terms with which we seek to understand them. On the one hand, as I intended to highlight, by means of the Internet, historians currently have access to sources that are constantly being built and rebuilt. In this case, we are dealing with fleeting constructions about time and the self - a unique and, therefore, fantastic challenge. On the other hand, we have equally the possibility of understanding the very construction of discourses on History, which has been revealed as equally challenging, especially for teachers. In both paths (and in so many others) we might have more doubts than certainties. And this is an instigating aspect: after all, in times of search engines, everything seems to begin with a question!

\section{References}

CASTELLS, Manuel. A galáxia da Internet: reflexões sobre a Internet, os negócios e a sociedade. Rio de Janeiro: J. Zahar, 2003. 243 p.

BERGMANN, Klaus. A História na reflexão didática. Dossiê história em quadro-negro: escola, ensino e aprendizagem. Revista Brasileira de História. São Paulo: v.9, n. 19, p. 2942, set.1989/fev.1990.

BRIGGS, Asa; BURKE, Peter. Uma história social da mídia: de Gutenberg à internet. Rio de Janeiro: J. Zahar, 2004. $377 \mathrm{p}$

BRESCIANO, Juan Andrés. La historiografía em el amanecer de la cultura digital. Uruguay; Ediciones Cruz del Sur, 2010.

CHARTIER, Roger. A história ou a leitura do tempo. 2.ed. Belo Horizonte: Autêntica, 2010. $77 \mathrm{p}$ 
COHEN, Daniel I.; ROSENZWEIG, Roy. Digital history: a guide to gathering, preserving, and presenting the past on the web. Washington D.C.: Center for History and New Media, George Mason University, 2005. Disponível: <http://chnm.gmu.edu/digitalhistory/>. Acesso em: 10 de fevereiro de 2014.

DANTAS, Camila Guimarães. O passado em bits: memórias e histórias na Internet. 2008, oof. Dissertação (Mestrado em Memória Social) - Universidade Federal do Estado do Rio de Janeiro, data, oo f. Rio de Janeiro, 2008.

FONSECA. T. Inaugurando a história e construindo a nação: discursos e imagens no ensino de história. 3. ed. Belo Horizonte: Autêntica, 2011.

HARTOG, F. Tempo e patrimônio. Varia HISTORIA, Belo Horizonte, v.22, n.36, p.261-273, jul./dez.2006. Disponível em: <http://www.scielo.br/pdf/vh/v22n36/v22n36a02.pdf>. Acesso em: 19 fev.2010.

GINZBURG, Carlo. História na era Google. In: Fronteiras do Pensamento 2010. Porto Alegre: 29 nov. 2010. Disponível em:

<https://www.youtube.com/watch?v=wSSHNqAbd7E>. Acesso em: 10 abr. 2014.

LÉVY, Pierre. Cibercultura. 2. ed. São Paulo: Ed. 34, 1999. 260 p.

LUCCHESI, Anita. Entre a Storiografia Digitale e a Digital History: um olhar comparativo. In: SEMINÁRIO VISÕES DO MUNDO CONTEMPORÂNEO, II, 2012, São Cristóvão - SE. Tema do evento: as estações da história: do grande inverno russo à primavera árabe, 2012. Disponível em:

https://www.academia.edu/2310957/Entre_a_Storiografia_Digitale_e_a_Digital_History_u m_olhar_comparativo

LUCCHESI, A. Histórias no ciberespaço: viagens sem mapas, sem referências e sem paradeiros no território incógnito da Web. Cadernos do Tempo Presente, v. 6, p. 2, 2012.

LUCCHESI, A. História e historiografia digital: diálogos possíveis em uma nova esfera pública. In: SIMPÓSIO NACIONAL DE HISTÓRIA: CONHECIMENTO HISTÓRICO E DIÁLOGO SOCIAL, XXVII, 2013, Natal. Anais eletrônicos...Natal: ANPUH, 2013. Disponível em: <http://www.snh2013.anpuh.org/resources/anais/27/1372190846_ARQUIVO_AnitaLucchesi -HistoriaeHistoriografiaDigital-dialogospossiveisemumanovaesperapublica-ANPUH2013final.pdf.> Acesso em: 12 abr. 2014.

PLA, Sebastián. LEDESMA, Xavier Rodríguez. TUITEROS HISTÓRICOS: ENTRE LA VIEJA HISTORIA ESCOLAR Y LOS NUEVOS USOS PÚBLICOS DE LA HISTORIA. OPSIS, Catalão, v. 13, n. 1, p. 137-157 - jan./jun. 2013 Disponível em: http://www.revistas.ufg.br/index.php/Opsis/article/view/20967/15179\#.U_aTI8VdX-s. acesso em 15 de abril de 2014. 
POIRRIER, Philippe. Internet et les historiens. In: DELACROIX Christian, DOSSE François, GARCIA Patrick et OFFENSTADT Nicolas (Dir.). Historiographies. concepts et débats. Paris: Gallimard, 2010. p. 468-475.

RODRIGUES, Pedro Eurico. Do on-line para o off-line: sociabilidades e cultura escrita proporcionadas pela internet no Brasil do século XXI (2001-2010). 2012. oo f. Dissertação (Mestrado em História) - Universidade do Estado de Santa Catarina. Programa de PósGraduação em História (PPGHUDESC), Florianópolis, Disponível em: <http://www.faed.udesc.br/arquivos/id_submenu/482/pedroeuricorodrigues.pdf.> Acesso em: mar. 2014.

SCHMIDT, Maria Auxiliadora. BARCA. Isabel. MARTINS (Org.) Jörn Rüsen e o ensino de História. Curitiba. Editora da UFPR, 2010.

TOMASI, Julia Massucheti. "Eternamente Off-Line": as práticas do luto na rede social do Orkut no Brasil (2004-2011). 2013. 178 p. Dissertação (Mestrado em História) Universidade do Estado de Santa Catarina. Programa de Pós-Graduação em História (PPGHUDESC), Florianópolis. Disponível em: <http://www.faed.udesc.br/arquivos/id_submenu/784/julia_massucheti_tomasi.pdf.> Acesso em: mar. 2014.

SCHMIDT, Maria Auxiliadora. BARCA, Isabel. REZENDE, Estevão (Org.). Jorn Rüsen e o ensino de história. Curitiba, UFPR, 2010.

SARLO, Beatriz. Tempo passado: cultura da memória e guinada subjetiva. São Paulo: Companhia das Letras, 2007. 